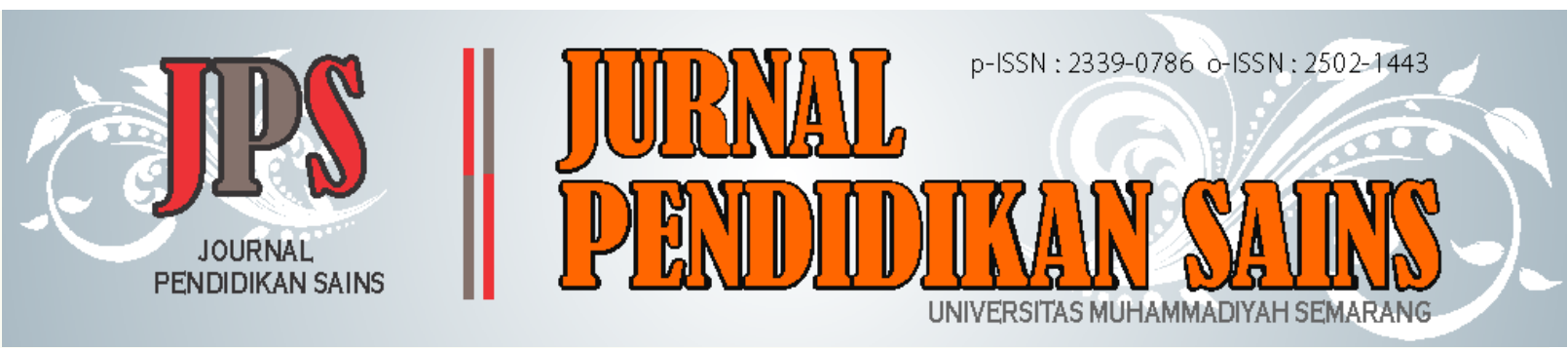

\title{
Development Of Instructional Design Project-Based Learning Model Integrated Science Process Skills To Improve Science Literacy
}

\author{
Nuraini $^{\text {a,1 }}$, Edy Waluyo ${ }^{\text {a,2,* }}$ \\ ${ }^{\text {a }}$ Faculty of Mathematics and Natural Sciences, Universitas Hamzanwadi, Jl. TGKH.M.Zainuddin Abdul Majid, No. 132 \\ Pancor, Selong, Lombok Timur, Nusa Tenggara Barat, Indonesia \\ ${ }^{1}$ nuraeni@hamzanwadi.ac.id; ${ }^{2}$ edywaluyo@ hamzanwadi.ac.id \\ * corresponding author : edywaluyo@ hamzanwadi.ac.id
}

\begin{tabular}{ll}
\hline \multicolumn{2}{l}{ Article history } \\
Submission & $: 2021-02-20$ \\
Revised & $: 2021-04-05$ \\
Accepted & $: 2021-04-20$
\end{tabular}

\section{Keyword}

Project-Based learning, Process Skills, Literacy

\begin{abstract}
Facing today's 21st-century learning, teachers need to foster science literacy and consider learning strategies that suit the conditions and potentials of students whose learning process focuses on providing hands-on experience and the application of scientific knowledge. Literacy skills are fundamental things that students must do in the face of the global era to meet the needs of life in various situations. This research aims to develop instructional design through science process skill-based project learning to improve useful, practical, and effective literacy skills. This research uses a type of research development model Borg and Gall, a systemic process that starts from the analysis of needs, product design, product development, implementation, and evaluation of products. The subjects in the research were grade VII students in Junior high schools Selong and Madrasah Tsanawiyah Muallimat NW Pancor numbered 64 people. Data collection uses validation sheets, practical guidelines, and tests to measure students' science literacy skills. The data is analyzed with descriptive analysis techniques. The analysis results showed that the instructional design of the project-based learning model based on science process skills falls into the category of valid, practical and effective, and feasible to use. The product developed also has a potential effect in improving students' science literacy skills indicated by an $\mathrm{N}$-Gain score of 0.77 with a high category.
\end{abstract}

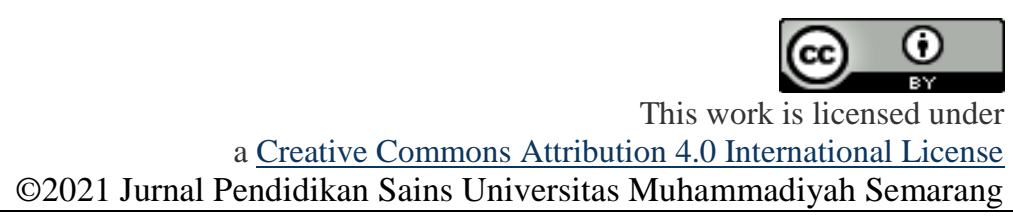

\section{INTRODUCTION}

The development of 21st-century science and technology today has changed the characteristics of learners and learning strategies in the classroom. The demands of the 21 st-century require the education system to conform to the changing times. Science literacy is critical for students to face the challenges of 21st-century development. Science literacy directly correlates with building a new generation with scientific solid thinking and attitudes that can effectively communicate science and research results to the public. One's science and technology literacy skills are characterized by the ability to solve problems using science concepts obtained according to their level, to know the technology products around them and their impact, to be able to use technology products, to be creative in making simplified technological https://jurnal.unimus.ac.id/index.php/JPKIMIA/index 
results so that students can make decisions based on the values and culture of society (Toharudin, 2011). Based on PISA data, the science literacy ability of Indonesian students is still below the average compared to the International average score. Indonesia's ranking in 2009 was ranked 57th out of 65 countries with a score of 383. In 2012 Indonesia was ranked 64th out of a total of 65 countries with a score of 382.

Furthermore, in 2015 Indonesia was ranked 64th out of 72 countries with 403 (OECD, 2015). TIMSS results in 2015 stated that the learning outcomes of Indonesian students ranked 44th out of 49 countries with an average score of 397 (Mullis, 2016). For the TIMSS 2019 survey, Indonesia did not participate in this survey (Mullis, 2020). Soft science literacy skills are related to the science learning process that has not provided opportunities for students to develop reasoning and problem-solving skills. Pisa study results in 2015 and TIMMS are evidence that education in Indonesia still emphasizes the aspects of lower-level thinking and rarely familiarizes students to use high-level thinking in dealing with and solving real problems (Yanti, 2019).

Project-Based Learning is a learning model that allows teachers to learn in the classroom by engaging in project work (Wena, 2014). Project-based learning is student-centered and allows students to conduct in-depth investigations on essential topics (Grant, 2003). Project-Based Learning is an activity where students can access knowledge and facilitate students in conducting investigations (Yulie, 2003). ProjectBased learning requires students to design and develop systems that can be used to investigate and solve real-world problems (Sababha, 2016). Project-Based Learning is a method in which students engage in intellectually challenging task assignments that encourage them to learn and solve complex problems (Movahedzadeh, 2012). Project-Based learning provides a structure for students to engage in every practice by developing and implementing the project (Baker, 2004). Project-Based Learning is a complex activity based on challenging questions or problems involving students in project design, problemsolving, decision making, or investigative activities and provides students with the opportunity to work independently to produce authentic products (Fitrina, 2016). Project-Based learning is effective learning to develop students' science process skills and science literacy knowledge (Omar, 2014; Tasiwan, 2015). Students who do Project Based Learning activities will have more significant learning outcomes than those who use regular learning as usual (Çakici \&Turkmen, 2013). Project-Based learning provides teachers with opportunities to motivate students to develop the right strategies, design projects, and investigate real problems. Student-centered learning can make students more critical, investigative, communicative, and interactive in conducting experiments (Farida, 2017).

Science process skills are intellectual, social, and physical insights or knowledge derived from fundamental abilities that are in principle already present in students (Tawil, 2014). The science process skills of science teachers are analyzed in two stages: basic and integrated process skills to provide more detail (Bulent, 2015). Science process skills can be divided into basic science process skills and integrated science process skills. Basic science process skills include observing, classifying, measuring, and using numbers, conclusion, predicting, communicating, and using space and time relationships. These skills need to be realized by teachers important in science learning and serve as scaffolding for other cognitive skills such as logical thinking, reasoning, and problem-solving skills. The instruction for the task must include e clear and valuable (Rauf, 2013). A person needs specific abilities such as observing, concluding, experimenting, or science process skills (Aktamis \& Omer, 2008). Science process skills are scientific thinking skills helpful in solving problems and formulating results (Ozgelen, 2012). Teachers should note some problems in skills where there are indications that student ownership of science process skills is low. This is important because it will allow teachers to encourage students who may lack relevant skills (Akani, 2015). By developing science process skills, students will discover and develop facts and concepts and add their own, developing attitudes and values (Semiawan, 2012). Science process skills are an essential and critical component of conducting science studies under the guidance of a teacher (Ango, 2002).

A science process is a skill that focuses on the learning process to develop student's skills in understanding knowledge or concepts, independently discovering and developing the necessary facts, concepts, and values (Siahaan, 2013). Science process skills are an essential and vital component of the learning process under the guidance of teachers during the learning process - essential components of science process skills, including (1) Observing. Using one or more of the five senses to pay attention to the characteristics of an object or event, (2) Conveying information through language, image, or other means of representation, (3) Classifying and putting items into categories according to specific 
characteristics, (4) Measuring. Make quantitative observations by comparing each other or with units of measure, (5) Related objects in space and time. Use the relationship of space and time in describing and comparing shapes, locations, movements, and patterns (Linda, 1993). The interaction between the development of science process skills with the facts, concepts, and principles of science will eventually develop the attitudes and values of scientists in students (Dimiyati, 2009). Science process skills become the basis for problem-solving by applying scientific methods ( Maknun, 2012).

Science literacy can be interpreted as scientific knowledge and proficiency to be able to identify questions, acquire new knowledge, explain scientific phenomena, and make fact-based decisions, understand science characteristics, awareness of how science and technology, intellectual, and culture, and willingness to engage and care about science-related issues (OECD, 2016). The main elements in science literacy are (1) concepts or ideas that can help understand the scientific aspects of the natural world and that enable students to understand new experiences by connecting knowledge at hand with what is already known, (2) processes, i.e., mental and physical skills used in acquiring, interpreting, and using experimental results to gain knowledge and build new understanding, (3) attitudes that demonstrate willingness and confidence to engage in further investigation, discussion, and learning, (4) understanding the nature and limitations of scientific knowledge (Harlen, 2004).

Facing today's 21st-century learning, teachers need to develop student science literacy and implement learning strategies that suit students' conditions and potentials, namely learning centered on providing hands-on experience and science process skills. Literacy skills are essential skills that students must have in facing the global era to meet the needs of life in various situations. Science literacy can understand science, communicate science, and apply science skills to solve problems. Based on the above, developing the instructional design with a project-based learning model integrated science process skills is necessary.

\section{METODE}

Referring to the research problems above, the research method used is Borg and Gall development research (2007) which is a systematic process carried out in developing products and refers to the development of learning design with stages of needs analysis, product design, product development, product implementation and evaluation (Dick \& Carey, 2001). The research was conducted on 32 students of grade VII D Madrasah Tsanawiyah Muallimat NW Pancor and 32 students of grade VII A SMPN 1 Selong. Data collection instruments consist of validation guidelines, practical guidelines, and tests on students' science literacy skills. The validation guidelines consist of 10 questions with indicators including (a) Aspects of formulation of learning objectives, (b) Aspects of content, (c) Aspects of language, and (d) Aspects of time. While the product practicality guidelines consist of 10 questions with indicators, among others: (a) Aspects of feeling good about the learning component, (b) Aspects of feeling novelty in learning, (c) Aspects of learning interest. While the tests on students' science literacy skills are prepared in the form of essay tests with indicators: (1) identifying scientific opinions, (2) conducting effective literature searches,(3) understanding the design of the investigation and how it impacts the findings/ conclusions, (4) charting the correct data, (5) solving problems using quantitative skills (Gormally, 2012).

Three validations do product validation in education. Namely, 1 learning material expert, one learning technology expert, and one expert/practitioner implementing learning and conducted trials to obtain a valid instrument. The quality of the development product in the form of instructional design project-based learning integrated science process skills in this study is based on validity criteria consisting of the validity of the construct and the validity of the content, practicality, and effectiveness. From the content aspect, the product developed is declared valid if the development process is carried out based on the theory of product development and refers to the demands of the characteristics of the learning model set. From the constructive aspect, instructional design is valid if there is a relationship between the characteristics of the learning model used in the integrated project-based learning model of science process skills and each component of the instructional design developed following the established eligibility criteria. Validation instruments are used to measure instructional design validity data with project-based learning integrated science process skills developed using criteria such as table 1 (Waluyo, 2020).

Table 1. Developed Instructional Design Validity Criteria 


\begin{tabular}{cl}
\hline Interval Score & Criteria \\
\hline $85<\mathrm{X}$ & Very Valid \\
\hline $70<\mathrm{X} \leq 85$ & Valid \\
\hline $55<\mathrm{X} \leq 70$ & Fairly Valid \\
\hline $40<\mathrm{X} \leq 55$ & Less Valid \\
\hline $\mathrm{X} \leq 40$ & Invalid \\
\hline
\end{tabular}

Product practicality testing is measured from two aspects, namely based on expert assessment and operational trials in the field. The practicality criteria of the developed product are measured by criteria such as Table 2

Table 2. Developed Instructional Design Practicality Criteria

\begin{tabular}{cl}
\hline Interval Score & Criteria \\
\hline $85<\mathrm{X}$ & Very Practical \\
\hline $70<\mathrm{X} \leq 85$ & Practical \\
\hline $55<\mathrm{X} \leq 70$ & Fairly Practical \\
\hline $40<\mathrm{X} \leq 55$ & Less Practical \\
\hline $\mathrm{X} \leq 40$ & Impractical \\
\hline
\end{tabular}

Testing the effectiveness of the developed product was conducted by looking at students' post-test scores on science literacy skills after taking part in the learning. Product effectiveness indicators are determined by the criteria of at least $80 \%$ of the number of students given tests on science literacy ability get a minimum score of 75 . As for testing whether the product developed has a potential effect in improving student science literacy is done by calculating the magnitude of $\mathrm{N}$ - Gain by using One Group Pretest Posttest Design.

\section{RESULT AND DISCUSSION}

\section{Preliminary Research}

Preliminary research was conducted to determine the characteristics of learning conducted by teachers in Madrasah Tsanawiyah NW Pancor and SMPN 1 Selong. Observations and interviews with teachers and students show that learning has not shown that the learning involving students in the learning and literacy of science students has not been adequately developed. Meanwhile, based on questionnaires given to 30 grade VII students of Madrasah Tsanawiyah NW Pancor and SMPN 1, Selong showed that 78.35\% of students felt that in learning, teachers have not fully provided opportunities for students to develop science literacy skills in solving problems in science learning. It is necessary to develop an instructional design that can engage students in learning activities and develop student science literacy.

Product Design

Product development in the form of instructional design project-based learning integrated science process skills. The product is developed following the stages of learning activities that refer to the projectbased learning model integrated science process skills, namely: 1) starting with essential questions, taking topics that correspond to real-world realities, and starting with investigation using students' science skills, 2) Project work planning and selection of activities related to science skills in answering essential questions, 3) arranging the schedule of activities, 4) monitoring the progress of student projects, 5) assessment of student project results, 6) evaluation of student learning experience.

\section{Product Validation}

Three experts validated the product draft: learning materials experts, learning technology experts, and learning practitioners. Expert validation is performed to get feedback, suggestions, comments, and corrections to the initial product for further improvement to improve the product. Analysis of validation data by experts concerning validity criteria as in table 1 . The validation results of the experts show that the products developed fall into a valid category and are presented as in Table 3 
Table 3. Product Validation Results by Experts

\begin{tabular}{lccc}
\hline \multirow{2}{*}{ Components } & \multicolumn{2}{c}{ Validation Results } & Validator III \\
\cline { 2 - 4 } & Validator I & Validator II & 9.0 \\
\hline Identity & 9.0 & 9.2 & 8.4 \\
\hline Goal Formulation & 8.5 & 8.3 & 7.3 \\
\hline Indicator Formulation & 7.5 & 7.8 & 7.8 \\
\hline Material Expansion & 8.0 & 7.8 & 8.3 \\
\hline Learning Strategies & 8.0 & 8.1 & 8.4 \\
\hline Learning Activities & 8.5 & 8.3 & 7.9 \\
\hline Media Selection & 7.5 & 7.8 & 7.6 \\
\hline Selection of Learning Resources & 7.0 & 7.2 & 8.2 \\
\hline Assessment & 7.6 & 8.1 & 7.9 \\
\hline Language Usage & 7.8 & 7.3 & 80.8 \\
\hline Score Count & 80.0 & 79.9 & Valid \\
\hline Conclusion & Valid & Valid & \\
\hline
\end{tabular}

Based on the table above, the product developed falls into the excellent category of both the first, second, and third validators.

Practicality of Products

The product's practicality is based on the assessment score of practicality guidelines conducted by three learning experts using practicality criteria as in table 3. Based on the data collected that the product was developed in the form of an instructional design model, Project-based learning integrated science process skills fall into the practical category, as shown in Table 4 below

Table 4. Practicality Results of Developed Products

\begin{tabular}{clcccccc}
\hline \multirow{2}{*}{ No } & \multirow{2}{*}{ Observation Aspects } & \multicolumn{5}{c}{ Average Observation Results by Experts } \\
\cline { 3 - 8 } & & \multicolumn{3}{c}{ SMPN 1 Selong } & \multicolumn{3}{c}{ Mts Muallimat NW } \\
\cline { 3 - 8 } & & Meet 1 & Meet 2 & Mean & Meet.1 & Meet.2 & Mean \\
\hline 1 & Delivery of learning indicators & 8.5 & 8.1 & 8.3 & 8.2 & 8.4 & 8.3 \\
\hline 2 & Perception and Motivation & 8.3 & 8.6 & 8.45 & 8.1 & 8.2 & 8.15 \\
\hline 3 & Real Problems & 8.2 & 8.4 & 8.3 & 7.9 & 7.4 & 7.65 \\
\hline 4 & Designing a Science Project & 8.2 & 8.0 & 8.1 & 7.8 & 7.5 & 7.65 \\
\hline 5 & Structuring a Science Project Schedule & 7.8 & 8.1 & 7.95 & 8.1 & 7.9 & 8.0 \\
\hline 6 & Implementation Monitoring & 7.9 & 7.5 & 7.7 & 7.6 & 7.8 & 7.7 \\
\hline 7 & Results Assessment & 8.1 & 7.8 & 7.95 & 7.9 & 8.2 & 8.05 \\
\hline 8 & Evaluation of Results & 8.4 & 8.2 & 8.3 & 8.2 & 8.1 & 8.15 \\
\hline 9 & Class management & 8.5 & 8.3 & 8.4 & 7.8 & 7.8 & 7.8 \\
\hline 10 & Formulating Conclusions & 7.6 & 8,2 & 7.9 & 7.5 & 7.5 & 7.5 \\
\hline & Score Count & 81.5 & 81.2 & 81.35 & 79.1 & 78.8 & 78.95 \\
\hline & Conclusion & Practical & Practical & Practical & Practical & Practical & Practical \\
\hline
\end{tabular}

Table 3 above shows that, after field trials, namely by applying to learn using instructional design project-based learning model integrated science process skills show that the instructional design belongs to the practical category of both field trials conducted at SMPN 1 Selong and Madrasah Tsanawiyah Muallimat NW Pancor.

\section{Product Effectiveness}

The effectiveness of the developed product is seen from the student's post-test score related to science literacy ability. The science literacy test was given to grade VII A SMPN 1 Selong and VII D Mts Muallimat NW Pancor with 32 students. The criteria determine product effectiveness indicators. There 
are at least $80 \%$ of the number of students who obtain a science literacy ability score of at least 75 . The results of the analysis of science literacy ability score data can be seen in Table 5.

Table 5. Student Literacy Ability Test Results

\begin{tabular}{lccc}
\hline \multicolumn{4}{c}{ Student Literacy Proficiency Score } \\
\hline \multicolumn{1}{c}{ Subject } & Number of Students & ( Score $\geq 75)$ & Percentage \\
\hline Class VII A SMPN 1 Selong & 32 & 29 & 90,63 \\
\hline Class VII D Mts Muallimat NW & 32 & 28 & 87,50 \\
\hline Score Count & 64 & 57 & 89,06 \\
\hline
\end{tabular}

Based on the table above, it can be seen that out of the 32 students of grade VII A SMPN 1 Selong, there are 29 students or $80.63 \%$ who get a science literacy ability score $\geq$ of 75 . As for grade VII D Mts. Muallimat NW Pancor, out of 32 students, there were 28 students or $87.50 \%$ who scored science literacy skills $\geq 75$. Similarly, when viewed as a whole from 64 students, 57 students or $89.06 \%$ of students obtained a science literacy ability score $\geq$ of 75 . Thus, the product developed is an instructional design based on Project Based Learning integrated science process skills practical to use. Testing whether the learning design developed potential in improving science literacy skills is measured based on $\mathrm{N}$-Gain value, i.e., the difference in science literacy ability score between pretest and post-test field test results. Field trials were conducted during two meetings for grade VII A students of SMPN 1 Selong and students of grade VIID Mts Muallimat NW Pancor. The test results showed that the average pretest score of a student's science literacy skills was 32.30, and the average post-test score was 84.24. N-Gain scores, average pretest scores, and student science literacy ability post-tests are presented in the following table 6 .

Table 6. N-Gain Scores Pretes and Posttes Student Science Literacy Skills

\begin{tabular}{clcccc}
\hline Number of Students & \multicolumn{2}{c}{ Average } & \multicolumn{2}{c}{ Category } \\
\hline & Pre-test & Post-test & Gain & N-Gain & \\
\hline 64 & 32.30 & 84.24 & 51.94 & 0.77 & High \\
\hline
\end{tabular}

Based on table 6 above, it is obtained that the N-Gain value of 0.77 falls into the high category. This suggests that using project-based learning design in integrated science process skills has a high potential effect in improving students' science literacy skills. Learning with project-based learning begins with the presentation of essential issues. Students are asked to play an active role in conveying their ideas and ideas about material on essential issues in the learning. At the design stage of the project, students actively discuss conducting experiments; then, students present the results of their project. The series of activities carried out in ). Science learning with project-based learning integrated the proficiency of this scientific process is believed to create students' curiosity and improve students' science literacy skills. Learning with project-based learning integrated science process skills is required to provide answers to essential question questions and provide deductive and inductive conclusions to specific problems (Insyasiska, 2015). Students' active involvement in learning is believed to create curiosity so that students are interested in learning the material delivered by the teacher (Andana, 2014). Project-based learning integrated science process skills encourage students to be active and skilled in learning activities. Students understand the knowledge that must be possessed through project design and implementation. Through integrated project-based learning of science process skills, students can build knowledge through experience and experiment with each group member and between groups so that students' science process skills can be improved. Through integrated project-based learning science process skills, students' learning outcomes are better than learning using conventional learning models (Siwa, 2015). Projectbased learning integrated science process skills help design effective learning to potentially meet the demands of learning. Project-based learning integrated science process skills help students in: (1) strengthening meaningful knowledge and skills built through essential task assignments; (2) expand knowledge through investigation, with results or answers not determined by a particular perspective; and (3) build knowledge through real-world experiences that take place in a collaborative work environment. Through integrated project-based learning science and process skills, students can gain hands-on experience through the investigation process. Through hands-on experience, students can practice using their senses, gather evidence, and then follow up by asking questions or formulating hypotheses based on https://jurnal.unimus.ac.id/index.php/JPKIMIA/index 
existing ideas to potentially improve students' science literacy skills. Integrated project-based learning of science process skills allows students to be allowed to discuss in groups to develop science skills and science literacy. Through integrated project-based learning of science process skills, it encourages students to reflect on what they have done to be aware of the weaknesses and advantages they have made. (Murniyati, 2018). This results in improving students' science literacy.

\section{CONCLUSION}

Products in the form of instructional design with project-based learning integrated science process skills have been compiled and developed based on the analysis of needs and refers to the development stage of the project-based learning model integrated science process skills. Products in the form of instructional design with project-based learning model integrated science process skills developed with communicative stages and presentation sequences conducted sequentially that allow students with different learning speeds to be more organized, making it easier to achieve learning objectives effectively. The product developed has met the eligibility criteria both in terms of validity, practicality, and product effectiveness. The results of field trials show that instructional design with project-based learning integrated science process skills are classified as valid based on the results of validator assessments of both learning material validators, learning technology experts, and learning practitioners indicated by the assessment score from the validation sheet by the validator of 80.0 each; 79.9 and 80.8 and meet good categories based on specified validity criteria. The products developed also fall into the practical category based on practicality assessment scores by experts using set practicality criteria. Field trial results show that most students can use well-developed products. The product developed is also relatively effective, shown from the percentage of students who scored the science literacy ability test $\geq 75$ by $89.06 \%$ of all students who numbered 64 students higher than the product effectiveness indicator set by $80 \%$. The learning implementation plan also has a potential effect in improving students' science literacy skills, shown by a significant difference between pretest and post-test scores and an $\mathrm{N}$-Gain score of 0.77 in the high category.

\section{ACKNOWLEDGMENT}

The thank you was conveyed to the Ministry of Research and Technology, which has provided funding for this research through the Applied Research Grant excellence of Higher Education (PTUPT) in 2020

\section{REFERENCES}

Akani. (2015). Levels of Possession of Science Process Skills by Final Year Students. Colleges of Education in the South Eastern States. 6(27), 94-102

Aktamis, H \& Omer, E. (2008). The Effect of scientific process skills education on students' scientific creativity, science attitudes, and academic achievements. Asia-Pacific Forum on Science Learning and Teaching, 9,(1)

Andana, E., Raga, G., Nyoman, S. (2014). Pengaruh Model Pembelajaran Berbasis Proyek Terhadap Hasil Belajar IPA. Jurnal Mimbar PGSD Universitas Pendidikan Ganesha, 2 (1)

Ango, M. (2002). Mastery of Science Process Skills and Their Effective Use in the teaching of science. International Journal of Educology, 16(10)

Baker, E.,Trygg, B., Otto,P., M Tudor, M., \& Ferguson, L. (2004). Project-based Learning Model: Relevant Learning for the $21^{\text {st }}$ Century. Pacific Education Institute, 1-70

Borg, W.,R \& Gall. (2007). Education research: An Introduction. New York: Logman

Bulent, A. (2015). The Investigation of Science Process Skills of Science Teachers in Terms of Some Variables. Educational Research and Reviews, 10(5), 582-594

Çakici, Y., Türkmen, N. (2013). An Investigation of The Effect of Project-Based Learning Approach on Children's Achievement and Attitude in Science. The Online Journal of Science and Technology, $3(2)$

Dick, W \& L Carey, W. (2001). The systematic design of instruction. Illinois: Addison Wesley

Dimiyati. (2009). Belajar dan Pembelajaran. Jakarta : Rineka Cipta 
Farida, I., Hadiansah, Mahmud \& A.Munandar. (2017). Project Based Learning Design for Internalization of Environmental Literacy with Islamic Value. Journal Pendidikan IPA Indonesia, 6(2), 277-284

Fitrina, Ikhsan, Munzir, (2016). Peningkatan Kemampuan Berpikir Kreatif dan Komunikasi Matematis Siswa SMA melalui Model Pembelajaran Project Based Learning Berbasis Debat. Jurnal Didatik Matematika. 3(1), 2355-4185

Grant, M. (2003). Getting a Grip on Project-Based Learning Theory, Cases and Recommendations Meridian A Middle School. Computer Technologies Journal, 5(1)

Gormally, C., Peggy, B \& Mary. (2012). Developing a Test of Scientific Literacy Skills (TOLS) Measuring Undergraduates Evaluation of Scientific Information and Arguments CBE. Life Sciences Education, 11, 364-377

Harlen, W. (2004). The Teaching of Science. London : David Fulton Publisher

Insyasiska, D., Siti, Z \& Herawati, S. (2015). Pengaruh Project Based Learning Terhadap Motivasi Belajar. Jurnal Pendidikan Biologi, 7 (1)

Julie, E. (2003). Engineering Education is Problem Based or Project Based Learning The Answer. Australia asian Journal of Engineering Education, 4(1)

Linda, J. (1993). Engaging Children in Science. New York : Publishing Company

Maknun, J. (2012). Praktikum Ekologi Berbasis Proyek Media Pembekalan Pengetahuan Esensial Laboratorium. Jurnal Pendidikan MIPA, 13(1)

Mullis, I. V. S., Martin, M. O., Foy, P., Kelly, D. L., \& Fishbein, B. (2020). TIMSS 2019 International Results in Mathematics and Science. Retrieved from Boston College, TIMSS \& PIRLS International Study Center website: https://timssandpirls.bc.edu/timss2019/international-results/

Mullis, I. V. S., Martin, M. O., Foy, P., \& Hooper, M. (2016). TIMSS 2015 International Results in Mathematics. Retrieved from Boston College, TIMSS \& PIRLS International Study Center website: http://timssandpirls.bc.edu/timss2015/international-results/

Movahedzadeh F.,R Patwell,R., J. E Rieker,J.E \& T Gonzalez,T. (2012). Project-Based Learning to Promote Effective Learning in Biotechnology Courses. Education Research International, 1-8

Murniyati, W. (2018). Perbedaan Penerapan Model Project Based Learning (PJBL) dan Problrm Based Learning (PBL) Ditinjau dari Pencapaian Keterampilan Proses Siswa. PSEJ, 3(1)

OECD. (2015). PISA 2015. Results in Focus. Accessed from https://www.oecd.org/education/pisa-2015results-volume-i-9789264266490-en.htm

OECD (2016), PISA 2015 Assessment and Analytical Framework: Science, Reading, Mathematics and Financial Literacy. Paris: OECD Publishing. http://dx.doi.org/10.1787/9789264255425-en

Omar, R., Puteh, Sharifah N., Ikhsan, Zanaton. (2014). Implementation of Science Skills Process in Project-Based Learning Through Collaborative Action Research. ICER

Ozgelen, S. (2012). Students' science process skills within a cognitive domain framework. Eurasia Journal of Mathematics, Science \& Technology Education, 8(4), 283-292

Rauf, R., Rasul, M., Mansor, A., Othman, Z \& Lyndon, N. (2013). Inculcation of Science Process Skills in a Science Classroom. Asian Social Science, 9(8), 47-57

Sababha. (2016). Project-Based Learning to Enhance Teaching Embedded Systems. Eurasia Journal of Mathematics. Science \& Technology Education, 12(9)

Semiawan, C. (2012). Pendekatan Pengetahuan Proses. Jakarta : Gramedia

Siahaan, S. (2017). Improving Students' Science Process Skills through Simple Computer Simulations on Linear Motion Conceptions. J. Phys. Conf. Ser., 812

Siwa, I. (2013). Pengaruh Pembelajaran Berbasis Proyek dalam Pembelajaran Kimia terhadap Keterampilan Proses Sains Ditinjau Dari Gaya Kognitif Siswa. Journal Program pascasarjana, $3(1)$

Tasiwan. (2015). Efek Pembelajaran Berbasis Proyek Terbimbing Terhadap Perkembangan Keterampilan Proses dan Sikap Sains Siswa. Berkala Fisika Indonesia, 7(2).

Tawil, Liliasari. (2004). Pengetahuan Pengetahuan Sains dan Implementasinya dalam Pembelajaran IPA. Makasar :Universitas Hasanuddin

Toharudin, Hendrawati, S. (2011). Membangun Literasi Sains Peserta Didik. Bandung : Humaniora 
Waluyo, E., Supiyati, S., M Halqi, M. (2020). Mengembangkan Perangkat Pembelajaran Kalkulus Integral Berbasis Model Pengajuan dan Pemecahan Masalah untuk Meningkatkan Kemampuan Berpikir Kreatif Mahasiswa. Jurnal Elemen, 6,(2), 357- 366

Wena.(2014). Strategi Pembelajaran Inovatif Kontemporer. Jakarta : Bumi Aksara

Yanti, M.,Sudia M., Arapu, L. (2019). Pengaruh Model Pembelajaran Mind Mapping Terhadap Kemampuan Berpikir Kreatif matematis Peserta Didik Kelas VIII SMP Negeri 8 Konawe Selatan. Jurnal Penelitian Pendidikan Matematika, 7(3), 71-84 